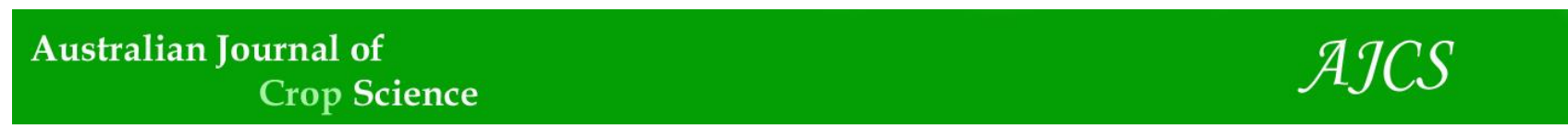

AJCS 13(12):1975-1982 (2019)

ISSN:1835-2707

doi: 10.21475/ajcs.19.13.12.p1918

\title{
Nitric oxide fumigation alleviates chilling injury and regulates fruit quality in sweet orange stored at different cold temperatures
}

\author{
Muneer Rehman ${ }^{1}$, Zora Singh ${ }^{2 *}$, Tahir Khurshid ${ }^{3}$ \\ ${ }^{1}$ School of Molecular and Life Sciences, Faculty of Science and Engineering, Curtin University, GPO Box U1987, Perth \\ 6845, Western Australia \\ ${ }^{2}$ Centre for Crop and Food Innovation, Western Australia State Agricultural Biotechnology Centre, College of \\ Science, Health, Engineering \& Education, Murdoch University, Perth, Western Australia 6150 \\ ${ }^{3}$ NSW Department of Primary Industries, Dareton, Australia
}

*Corresponding author: Z.Singh@murdoch.edu.au

\begin{abstract}
The cold storage of sweet oranges below $7{ }^{\circ} \mathrm{C}$ causes chilling injury and adversely affects fruit quality. Midknight Valencia and Lane Late sweet oranges were fumigated for 2 hours with different concentrations (5, 10 or $20 \mu \mathrm{L} \mathrm{L} \mathrm{L}^{-1}$ ) of nitric oxide (NO) and stored at $\left(4\right.$ or $7{ }^{\circ} \mathrm{C}$ ) to investigate the effect on chilling injury incidence $(\mathrm{Cl})$ and fruit quality after 90 days storage followed by 10 days simulated shelf conditions. Untreated fruit served as a control. The experimental design completely randomised with two factors including NO fumigation treatments and storage temperatures. All NO fumigation treatments $(5,10$ or $20 \mu \mathrm{L} \mathrm{L}-1)$ significantly reduced the $\mathrm{Cl}$ irrespective of storage temperature as compared to the control in both the cultivars. Fruit were fumigated with different concentration of $\mathrm{NO}$ gas in a sealed container for $2 \mathrm{~h}$ and then kept at $4^{\circ} \mathrm{C}$ and $7^{\circ} \mathrm{C}$. Fruit quality variables such as fruit firmness, SSC (\%), TA (\%), SSC/TA, sugars, vitamin C and total antioxidants were determined. All the NO treatments significantly reduced per cent weight loss as compared to control in Lane Late. Mean weight losses were higher ( $8.3 \%$ and $5.5 \%)$ when fruit were stored at $7{ }^{\circ} \mathrm{C}$ as compared to those stored at $4{ }^{\circ} \mathrm{C}(4.8 \%$ and $3.5 \%)$ in Midknight Valencia and Lane Late respectively. All the NO fumigation treatments significantly reduced the mean concentrations of glucose, fructose, sucrose and total sugars in the juice of Midknight Valencia only. All NO fumigation treatments significantly reduced mean concentration vitamin C in the fruit juice of Lane Late as compared to the control. Meanwhile, in Midknight Valencia, NO (10 or $20 \mu \mathrm{L} \mathrm{L}^{-1}$ ) fumigated fruit showed a significant reduction in the mean concentration of vitamin $C$ as compared to NO $\left(5 \mu \mathrm{L} \mathrm{L}^{-1}\right)$ fumigation and control. The juice of Midknight Valencia had higher mean total antioxidants when fumigated with NO $\left(5 \mu \mathrm{L} \mathrm{L}^{-1}\right)$ as compared to the control, but not in Lane Late. In conclusion, all the NO fumigation $\left(10 \mu \mathrm{L} \mathrm{L}^{-1}\right)$ treatment was most effective in reducing Clin both cultivars irrespective of the cold storage temperature. NO fumigation treatments did not affect SCC/TA ratio but reduced all the individual and total sugars as well as vitamin $\mathrm{C}$ in the fruit stored for 90 days followed by 10 days simulated shelf conditions.
\end{abstract}

Keywords: Nitric oxide (NO), storage temperatures, chilling injury, fruit quality.

Abbreviations: NO_Nitric oxide; $\mathrm{Cl}_{-}$Chilling injury; SSC_soluble solids concentration; TA_titratable acidity; ROS _ reactive oxygen species; $\mathrm{H}_{2} \mathrm{O}_{2}$ hydrogen peroxide; $\overline{\mathrm{O}}_{2} \cdot{ }_{-}^{-}$superoxide anion; $\mathrm{SNP}$ _ sodium nitroprusside; $\overline{C A T}_{-}$catalase; POD _ peroxidase; SOD superoxide dismutase; APX_ascorbate peroxidase.

\section{Introduction}

Chilling injury $(\mathrm{Cl})$, a major physiological disorder mainly develops in tropical and subtropical fruit when stored below $10-15{ }^{\circ} \mathrm{C}$ for a certain period of time (Ladaniya, 2010). Citrus is a non-climacteric fruit with a low level of ethylene and respiration rate (Kader, 2002). Low storage temperatures are used to extend the post-harvest life of fruit and vegetables (Lyons, 1973). Cl occurs due to temperature and time relationship, and the symptoms usually appear quite rapidly when the citrus fruit is kept at room temperature (Ladaniya, 2010). $\mathrm{Cl}$ disrupts the normal cell metabolism and negatively affects the fruit quality, one of the significant contributors to the post-harvest loss in citrus fruit (Sala et al., 2005). $\mathrm{Cl}$ in citrus fruit exhibits as rind staining, pitting, red blotches, scalding, watery breakdown, sunken tissues, damage to the styler end of lemons and necrosis on the flavedo (Reuther et al., 1989). It has been reported that $\mathrm{Cl}$ symptoms might be the result of oxidative stress from excess reactive oxygen species (ROS) that induces peroxidation and breakdown of unsaturated fatty acids in membrane lipids (Lyons, 1973).

Nitric oxide (NO), is a relatively stable, highly reactive free radical gas and acts as a multifunctional signalling molecule in many plant tissues (Wendehenne et al., 2001). It provides defence against biotic and abiotic stress and intricately involved in many physiological processes including ripening of climacteric and non-climacteric fruits (Besson-Bard et al., 2008; Xu et al., 2005). According to Wink and Mitchell (1998) NO probably act as an antioxidant that is capable to 
scavenge the ROS to protect plant cells from oxidative stress. In addition, Zhu at al. (2008) reported that ROS triggered oxidative stress, which was protected by the exogenous application of NO in kiwi fruit. It has been well documented that NO inhibits ethylene biosynthesis through the inhibition of ethylene biosynthesis enzymes and as a result delays ripening and senescence in many climacteric and non-climacteric fruit (Wills et al., 2000). On the contrary, Huque et al. (2013) reported that NO-induced the inhibition of browning in apple slices without affecting ethylene production. In addition, NO also reduced cell respiration by inhibiting the cytochrome pathway in mitochondria (Millar and Day, 1996; Zottini et al., 2002).

Furthermore, post-harvest application of $\mathrm{NO}$ has been reported to alleviate chilling injury and maintain fruit quality in climacteric fruit such as Japanese plum cv Amber Jewel (Singh et al., 2009), banana (Musa spp., AAA group cv. Brazil) (Wang et al., 2013), peach (Prunus persica (L.) Batsch, cv. Feicheng) (Zhu et al., 2010), mango (Mangifera indica L. cv. Kensington Pride) (Zaharah and Singh, 2011), banana (Wang et al., 2013; Wu et al., 2014), papaya (Li et al., 2014), tomato (Zhao et al., 2011), peach ( Zhu et al., 2010; Flores et al., 2008), kiwifruit (Zhu et al., 2008), Yali pears (Liu et al., 2011) and non-climacteric fruit Chinese bayberry (Wu et al., 2012), loquat (Xu et al., 2012), longan (Duan et al., 2007) and strawberry (Wills et al., 2000). Recently, Ghorbani et al. (2018) reported that a $0.5 \mathrm{mM}$ SNP (sodium nitroprusside) 5 min dip treatment increases antioxidant enzyme activity and reduced $\mathrm{Cl}$ in Washington navel orange stored for five months at $3{ }^{\circ} \mathrm{C}$. However, the effect of NO fumigation on quality of cold stored sweet orange fruit is yet to be investigated. To our knowledge, no research work has been reported on the effect of NO fumigation to alleviate $\mathrm{Cl}$ and maintain fruit quality in Midknight Valencia and Lane Late sweet orange cultivars. The aim of the present study was to investigate the effect of NO on regulating the incidence of chilling injury and fruit quality in cold stored fruit $\left(4{ }^{\circ} \mathrm{C}\right.$ and 7 ${ }^{\circ} \mathrm{C}$ for 90 days followed by 10 days of simulated shelf conditions) in Midknight Valencia and Lane Late sweet orange.

\section{Results}

\section{Effect of NO fumigation on chilling injury}

Fumigation treatments of NO significantly $(P<0.05)$ reduced mean $\mathrm{Cl}$ (\%) on the fruit as compared to the control in Midknight Valencia and Lane Late stored for 90 days followed by 10 days simulated shelf conditions (Table 1). However, $\mathrm{Cl} \%$ was significantly lower when fruit were stored at $7{ }^{\circ} \mathrm{C}(2.2,4.2 \%)$ as compared to those kept at $4{ }^{\circ} \mathrm{C}$ (6.9, $11.2 \%$ ) in Midknight Valencia and Lane Late respectively. The interaction effects were not significant between treatments and storage temperatures for $\mathrm{Cl}$ in both cultivars.

\section{Effect of NO fumigation on weight loss}

Weight loss (\%) in Lane Late was significantly $(P<0.05)$ reduced with all NO fumigation treatments irrespective of the concentrations applied; it was not affected in Midknight Valencia (Table 2). However, weight loss (\%) was significantly higher once fruit were stored at $7{ }^{\circ} \mathrm{C}(8.3$ and $5.5 \%)$ compared to those kept at $4{ }^{\circ} \mathrm{C}(4.8$ and $3.5 \%)$ respectively, for both Midknight and Lane Late. The interaction effects between different treatments and cold storage temperatures were not significant for Midknight Valencia and Lane Late.

\section{Effect of NO fumigation on fruit firmness}

NO fumigation treatments and cold storage temperatures did not significantly $(P<0.05)$ affect fruit firmness $(N)$ in 90 days cold stored followed by 10 days simulated shelf conditions in Midknight Valencia and Lane Late oranges (Table 3). The interaction effects were also not significant for both cultivars.

\section{Effect of NO fumigation on soluble solids content (SSC \%) of the juice}

All treatments except NO $\left(5 \mu \mathrm{L} \mathrm{L}^{-1}\right)(12.2 \%)$ significantly $(P<$ $0.05)$ increased SSC \% in the fruit juice of 90 days cold stored followed by 10 days simulated shelf conditions in Midknight Valencia and was not significant in Lane Late navel (Table 4). However, SSC (\%) was significantly higher in the juice of fruit stored at $7{ }^{\circ} \mathrm{C}(12.8,11.8 \%)$ than those stored at $4{ }^{\circ} \mathrm{C}(12.3$, $11.4 \%)$ in Midknight Valencia and Lane Late, respectively. The interaction was found to be significant for Midknight Valencia but not Lane Late. In Midknight Valencia, NO (10 or $20 \mu \mathrm{L} \mathrm{L}^{-1}$ ) fumigation treatments increased SSC (\%) (12.5 and $12.7 \%)$ respectively, as compared to all other treatments.

\section{Effect of NO fumigation on titratable acidity (TA \%) of the juice}

NO fumigation treatments showed significantly $(P<0.05)$ reduced mean TA $(\%)$ regardless of the concentrations applied as compared to the control after 90 days of cold storage followed by 10 days simulated shelf conditions (Table 4). Moreover, mean TA (\%) was significantly higher in the fruit juice stored at $4{ }^{\circ} \mathrm{C}(0.66,0.55 \%)$ than those stored at $7{ }^{\circ} \mathrm{C}(0.54,0.53 \%)$ in Midknight Valencia and Lane Late, respectively. The interaction between NO treatments and storage temperatures for TA (\%) was found to be significant in Midknight Valencia but not in Lane Late. In Midknight Valencia, all NO fumigation treatments except NO $\left(5 \mu \mathrm{L} \mathrm{L}^{-1}\right)$ showed higher TA (\%) in the juice.

\section{Effect of NO fumigation on SSC/TA ratio of the juice}

NO fumigation treatments did not significantly $(P<0.05)$ affect SSC/TA ratio in Midknight Valencia and Lane Late after 90 days of cold storage followed by 10 days simulated shelf conditions (Table 4). However, SSC/TA ratios were significantly higher in fruit juice stored at $7{ }^{\circ} \mathrm{C}(23.5,22.5 \%)$ than those stored at $4{ }^{\circ} \mathrm{C}(18.6,20.7 \%)$ for Midknight Valencia and Lane Late, respectively. The interaction effects were not significant for both cultivars.

\section{Effect of NO fumigation on the levels of glucose in the juice}

All NO fumigation treatments irrespective of the concentrations applied showed significantly $(P<0.05)$ reduced glucose levels in fruit juice of Midknight Valencia and did not affect Lane Late after 90 days of cold storage 
followed by 10 days simulated shelf conditions (Table 5). Moreover, mean glucose levels were higher in fruit juice of Midknight Valencia and Lane Late navel stored at $7{ }^{\circ} \mathrm{C}$ (15.6, $15.4 \%)$ than those stored at $4^{\circ} \mathrm{C}(13.3,13.5 \%)$ respectively. The interaction effects between different NO treatments and storage temperature were significant only for Midknight Valencia and the NO fumigation treatments reduced glucose levels in fruit juice as compared to the control at both storage temperatures.

\section{Effect of NO fumigation on the levels of fructose in the juice}

In Midknight Valencia, irrespective of the concentrations applied, all NO fumigation treatments reduced the fructose levels in fruit juice as compared to the control $\left(24.6 \mathrm{~g} \mathrm{~L}^{-1}\right)$ after 90 days of cold storage followed by 10 days simulated shelf conditions and were found to be non-significant in Lane Late (Table 5). However, mean fructose levels were higher in the fruit juice stored at $7{ }^{\circ} \mathrm{C}\left(23.7 \mathrm{~g} \mathrm{~L}^{-1}\right)$ compared to $4^{\circ} \mathrm{C}\left(22.2 \mathrm{~g} \mathrm{~L}^{-1}\right)$ in Midknight Valencia only. The interaction effects were significant for Midknight Valencia not for Lane Late. All the NO treatments except NO $\left(20 \mu \mathrm{L} \mathrm{L}^{-1}\right)$ reduced fructose levels in fruit juice of Midknight Valencia as compared to the control stored at $4{ }^{\circ} \mathrm{C}$ and $7^{\circ} \mathrm{C}$.

\section{Effect of NO fumigation on the levels of sucrose in the juice}

Sucrose levels in fruit juice of Midknight Valencia were reduced by all NO fumigation treatments regardless of the concentrations applied as compared to the control $\left(54.5 \mathrm{~g} \mathrm{~L}^{-}\right.$ $\left.{ }^{1}\right)$ after 90 days of cold storage followed by 10 days simulated shelf condition but was not reduced in Lane Late navel (Table 5). However, sucrose levels in fruit juice were higher (53.6 $\left.\mathrm{g} \mathrm{L}^{-1}\right)$ when stored at $4{ }^{\circ} \mathrm{C}$ compared to fruit stored at $7{ }^{\circ} \mathrm{C}\left(51.1 \mathrm{~g} \mathrm{~L}^{-1}\right)$ in Midknight Valencia only. The interaction effects were not significant for both cultivars.

\section{Effect of NO fumigation on the levels of total sugars in the juice}

In Midknight Valencia, all the fruit fumigated with NO irrespective of the concentrations reduced total sugars in fruit juice as compared to the control $\left(95.1 \mathrm{~g} \mathrm{~L}^{-1}\right)$ after 90 days of cold storage followed by 10 days simulated shelf conditions (Table 5). The interaction effects between different treatments and cold storage temperature were not for both cultivars.

\section{Effect of NO fumigation on the levels of vitamin C in the juice}

Vitamin C levels were reduced in fruit juice of Midknight Valencia and Lane Late with NO fumigation treatment irrespective of concentrations applied except NO $\left(5 \mu \mathrm{L} \mathrm{L}^{-1}\right)$ ( $357.4 \mathrm{mg} \mathrm{L}^{-1}$ ) in Midknight Valencia as compared to control after 90 days of cold storage followed by 10 days simulated shelf conditions (Table 6). On the other hand, mean vitamin $\mathrm{C}$ levels were higher in fruit stored at $7{ }^{\circ} \mathrm{C}\left(362.4 \mathrm{mg} \mathrm{L}^{-1}\right)$ than those stored at $4{ }^{\circ} \mathrm{C}\left(282.0 \mathrm{mg} \mathrm{L}^{-1}\right)$ in Midknight Valencia only. The interaction effects for vitamin $\mathrm{C}$ levels were significant in Midknight Valencia only. NO treatments reduced the level of vitamin C except NO $\left(5 \mu \mathrm{L} \mathrm{L}^{-1}\right)(416.1 \mathrm{mg}$ $\left.\mathrm{L}^{-1}\right)$ as compared to the control and all other treatments.

\section{Effect of NO fumigation on the levels of total antioxidants} in the juice

In Midknight Valencia, NO (5 or $20 \mu \mathrm{L} \mathrm{L}^{-1}$ ) increased levels of total antioxidants (416.5 or $383.3 \mu \mathrm{M}$ Trolox $\left.\mathrm{L}^{-1}\right)$ as compared to the control ( $369.3 \mu \mathrm{M}$ Trolox $\left.\mathrm{L}^{-1}\right)$ and other treatments after 90 days of cold storage followed by 10 days simulated shelf conditions but not in Lane Late navel (Table $6)$. The interaction effects were significant in Midknight Valencia only.

\section{Discussion}

Chilling injury symptoms adversely affect the cosmetic appearance of the fruit and deteriorate the quality in tropical and subtropical fruit including sweet oranges and mandarins. Chilling temperatures have been reported to cause oxidative burst as a result of over-production of reactive oxygen species (ROS), such as hydrogen peroxide $\left(\mathrm{H}_{2} \mathrm{O}_{2}\right)$ and superoxide anion $\left(\mathrm{O}_{2}{ }^{-}\right)$consequently increases lipid peroxidation and ultimately leading to cellular membrane damage (Xie et al., 2008). Previously, Sala (1998) has reported that oxidative stress was involved in coldinduced rind damage in Nova and Fortune cultivars of mandarins. Post-harvest NO fumigation reduced $\mathrm{Cl}$ in Midknight Valencia and Lane Late after 90 days of cold storage followed by 10 days simulated shelf conditions (Table 1). Possibly, NO fumigation application may have prevented membrane damage and enhanced chilling tolerance in Midknight Valencia and Lane Late orange through the enhanced activity of antioxidants in the peel by detoxifying reactive oxygen species. Similarly, Ghorbani et al. (2018) also reported that application of $0.5 \mathrm{mM}$ sodium nitroprusside (SNP) as a NO donor was able to reduce $\mathrm{Cl}$ in Washington navel orange stored at $3{ }^{\circ} \mathrm{C}$ through the increased response of antioxidants and reduced level of lipid peroxidation and $\mathrm{H}_{2} \mathrm{O}_{2}$ content. Additionally, $\mathrm{NO}$ treatment increased the activities of catalase (CAT), peroxidase (POD), superoxide dismutase (SOD) and ascorbate peroxidase (APX) under chilling stress in Washington navel orange (Ghorbani et al., 2018). Zhu et al. (2008) also reported related results that NO treated kiwi fruit had higher activities of SOD, CAT, APX and POD and higher DPPH-radical scavenging activity than control fruit during the storage. Previously, Manjunatha et al. (2010) also reported that NO has antioxidant properties and also plays an important role in the ROS metabolism and signalling network during normal and stress conditions. NO fumigation has been previously reported to reduced $\mathrm{Cl}$ and maintain fruit quality in many nonclimacteric horticulture crops such as strawberry (Zhu and Zhou, 2007; Wills et al., 2000), Chinese bayberry (Wu et al., 2012), cucumber (Yang et al., 2011), Chinese winter jujube (Zhu et al., 2009), longan (Duan et al., 2007), loquat (Xu et al., 2012) and sweet potato (Yin et al., 2012). Furthermore, Japanese plums fumigated with $\mathrm{NO}$ showed reduced $\mathrm{Cl}$ symptoms during storage at $0{ }^{\circ} \mathrm{C}$ for 6 weeks (Singh et al., 2009).

Enhanced chilling tolerance by reduced ethylene production and respiration rate with the application of NO has earlier been reported in Kensington Pride mango (Zaharah and Singh, 2011). The development of $\mathrm{Cl}$ in relation to ethylene production in various climacteric and non-climacteric fruit are multifarious, with no dependable relationship (Watkins 
Table 1. $\mathrm{Cl}(\%)$ affected by different concentrations of NO fumigation and cold storage temperatures $\left(4\right.$ or $\left.7^{\circ} \mathrm{C}\right)$ for 90 days followed by 10 days of simulated shelf conditions $\left(21 \pm 1^{\circ} \mathrm{C}\right)$ on Midknight Valencia and Lane Late.

\begin{tabular}{|c|c|c|c|c|c|c|}
\hline \multicolumn{7}{|c|}{$\mathrm{Cl}(\%)$} \\
\hline & Midknight Valencia & & Lane Late & & & \\
\hline $\begin{array}{l}\text { Treatments } \\
\left(\mu \mathrm{L} \mathrm{L}^{-1}\right)\end{array}$ & $4{ }^{\circ} \mathrm{C}$ & $7{ }^{\circ} \mathrm{C}$ & $\begin{array}{l}\text { Mean } \\
(\mathrm{Tr})\end{array}$ & $4{ }^{\circ} \mathrm{C}$ & $7{ }^{\circ} \mathrm{C}$ & $\begin{array}{l}\text { Mean } \\
(\mathrm{Tr})\end{array}$ \\
\hline Control & $12.5 \pm 0.6$ & $8.8 \pm 0.5$ & $10.6 a$ & $18.3 \pm 1.4$ & $15.0 \pm 1.4$ & $16.7 a$ \\
\hline NO (5) & $7.5 \pm 0.6$ & $0.0 \pm 0$ & $3.8 \mathrm{~b}$ & $11.7 \pm 1.8$ & $1.7 \pm 0.7$ & $6.7 \mathrm{~b}$ \\
\hline NO (10) & $3.8 \pm 0.5$ & $0.0 \pm 0$ & $1.9 b$ & $6.7 \pm 1.2$ & $0.0 \pm 0$ & $3.3 b$ \\
\hline NO (20) & $3.8 \pm 0.5$ & $0.0 \pm 0$ & $1.9 \mathrm{~b}$ & $8.3 \pm 1.4$ & $0.0 \pm 0$ & $4.2 b$ \\
\hline Mean (ST) & $6.9 a$ & $2.2 b$ & & $11.2 \mathrm{a}$ & $4.2 b$ & \\
\hline
\end{tabular}

Data represent means of 4 replicate samples of 80 units for Midknight Valencia and Lane Late. Mean separation for significant analysis of variance within the columns and rows was tested using Duncan's multiple range test at $(P<0.05)$. Mean followed by the same letter is not significantly different within the columns or rows. Standard error (SE \pm ). Treatments (Tr), Storage temperature (ST).

Table 2. Percent weight loss in Midknight Valencia and Lane Late sweet orange fruit influenced by different concentrations of NO fumigation and two cold storage temperatures $\left(4\right.$ or $\left.7^{\circ} \mathrm{C}\right)$ for 90 days.

\begin{tabular}{|c|c|c|c|c|c|c|}
\hline \multicolumn{7}{|c|}{ Weight loss (\%) } \\
\hline & & Lane Late & & & & \\
\hline $\begin{array}{l}\text { Treatments } \\
\left(\mu \mathrm{L} \mathrm{L}^{-1}\right)\end{array}$ & $4{ }^{\circ} \mathrm{C}$ & $7^{\circ} \mathrm{C}$ & $\begin{array}{l}\text { Mean } \\
(\mathrm{Tr})\end{array}$ & $4^{\circ} \mathrm{C}$ & $7^{\circ} \mathrm{C}$ & $\begin{array}{l}\text { Mean } \\
(\mathrm{Tr})\end{array}$ \\
\hline Control & $4.5 \pm 0.11 c$ & $8.0 \pm 0.20 a$ & 6.2 & $5.3 \pm 0.3 a$ & $5.5 \pm 0 a$ & $5.4 a$ \\
\hline NO (5) & $3.9 \pm 0.10 c$ & $9.0 \pm 0.20 \mathrm{a}$ & 6.5 & $2.9 \pm 0.1 b$ & $5.9 \pm 0 a$ & $4.4 b$ \\
\hline NO (10) & $5.6 \pm 0.17 b$ & $8.3 \pm 0.15 a$ & 7.0 & $2.8 \pm 0 \mathrm{~b}$ & $5.4 \pm 0 \mathrm{a}$ & $4.1 b$ \\
\hline NO (20) & $5.0 \pm 0.11 b c$ & $7.9 \pm 0.09 a$ & 6.4 & $3.1 \pm 0 b$ & $5.1 \pm 0.1 a$ & $4.1 b$ \\
\hline Mean (ST) & $4.8 b$ & $8.3 a$ & & $3.5 b$ & $5.5 a$ & \\
\hline
\end{tabular}

Data represent means of 4 replicate samples of 80 units for Midknight Valencia and Lane Late. Mean separation for significant analysis of variance within the columns and rows was tested usin Duncan's multiple range test at $(P<0.05)$. Mean followed by the same letter is not significantly different within the columns or rows. Standard error (SE \pm ). Treatments (Tr), Storage temperature (ST).

Table 3. Compression (N) in Midknight Valencia and Lane Late influenced by different concentrations of NO fumigation and two cold storage temperatures $\left(4\right.$ or $7^{\circ} \mathrm{C}$ ) for 90 days followed by 10 days of simulated shelf conditions $\left(21 \pm 1{ }^{\circ} \mathrm{C}\right)$.

\begin{tabular}{|c|c|c|c|c|c|c|}
\hline \multicolumn{7}{|c|}{ Fruit firmness $(\mathrm{N})$} \\
\hline & Midknight Valencia & Lar & & & & \\
\hline $\begin{array}{l}\text { Treatments } \\
\left(\mu \mathrm{L} \mathrm{L}^{-1}\right)\end{array}$ & $4{ }^{\circ} \mathrm{C}$ & $7^{\circ} \mathrm{C}$ & $\begin{array}{l}\text { Mean } \\
(\mathrm{Tr})\end{array}$ & $4{ }^{\circ} \mathrm{C}$ & $7^{\circ} \mathrm{C}$ & $\begin{array}{l}\text { Mean } \\
(\mathrm{Tr})\end{array}$ \\
\hline Control & $286.3 \pm 2.0$ & $288.0 \pm 7.6$ & 287.2 & $286.3 \pm 2.0$ & $288.0 \pm 7.6$ & 287.2 \\
\hline NO (5) & $303.4 \pm 6.8$ & $292.0 \pm 3.0$ & 297.7 & $303.4 \pm 6.8$ & $292.0 \pm 3.0$ & 297.7 \\
\hline NO (10) & $288.5 \pm 4.8$ & $280.8 \pm 3.7$ & 284.7 & $288.5 \pm 4.8$ & $280.8 \pm 3.7$ & 284.7 \\
\hline NO (20) & $283.4 \pm 4.6$ & $285.9 \pm 2.3$ & 284.6 & $283.4 \pm 4.6$ & $285.9 \pm 2.3$ & 284.6 \\
\hline Mean (ST) & 290.4 & 286.7 & & 290.4 & 286.7 & \\
\hline
\end{tabular}

Data represent means of 4 replicate samples of 80 units for Midknight Valencia and Lane Late. Mean separation for significant analysis of variance within the columns and rows was tested using Duncan's multiple range test at $(P<0.05)$. Mean followed by the same letter is not significantly different within the columns or rows. Standard error (SE \pm ). Treatments (Tr), Storage temperature

Table 4. SCC, TA and SSC/TA ratio in Midknight Valencia and Lane Late sweet orange fruit influenced by different concentrations of NO fumigation and two cold storage temperatures $\left(4\right.$ or $\left.7^{\circ} \mathrm{C}\right)$ for 90 days followed by 10 days of simulated shelf conditions $\left(21 \pm 1^{\circ} \mathrm{C}\right)$.

\begin{tabular}{|c|c|c|c|c|c|c|}
\hline \multicolumn{7}{|c|}{ SSC (\%) } \\
\hline & Midknight Valencia & Lane L & & & & \\
\hline $\begin{array}{l}\text { Treatments } \\
\left(\mu \mathrm{L} \mathrm{L}^{-1}\right)\end{array}$ & $4^{\circ} \mathrm{C}$ & $7^{\circ} \mathrm{C}$ & $\begin{array}{l}\text { Mean } \\
(\mathrm{Tr})\end{array}$ & $4{ }^{\circ} \mathrm{C}$ & $7^{\circ} \mathrm{C}$ & $\begin{array}{l}\text { Mean } \\
(\mathrm{Tr})\end{array}$ \\
\hline Control & $12.1 \pm 0.03 b c$ & $12.8 \pm 0.11 \mathrm{a}$ & $12.5 a b$ & $12.1 \pm 0.1$ & $11.7 \pm 0.1$ & 11.9 \\
\hline NO (5) & $11.7 \pm 0.07 c$ & $12.7 \pm 0.13 a$ & $12.2 b$ & $10.9 \pm 0.1$ & $11.6 \pm 0.2$ & 11.3 \\
\hline NO (10) & $12.5 \pm 0.05 a b$ & $12.8 \pm 0.02 a$ & $12.6 a$ & $11.4 \pm 0.1$ & $12.0 \pm 0$ & 11.7 \\
\hline NO (20) & $12.7 \pm 0 \mathrm{a}$ & $12.7 \pm 0.04 a$ & $12.7 a$ & $11.1 \pm 0.2$ & $11.9 \pm 0.1$ & 11.5 \\
\hline Mean (ST) & $12.3 \mathrm{~b}$ & $12.8 \mathrm{a}$ & & $11.4 \mathrm{~b}$ & $11.8 \mathrm{a}$ & \\
\hline \multicolumn{7}{|c|}{ TA (\%) } \\
\hline Control & $0.70 \pm 0.01 a$ & $0.55 \pm 0 c$ & $0.62 a$ & $0.58 \pm 0$ & $0.57 \pm 0$ & $0.57 a$ \\
\hline NO (5) & $0.61 \pm 0.01 b$ & $0.55 \pm 0 c$ & $0.58 b$ & $0.54 \pm 0$ & $0.52 \pm 0$ & $0.53 b$ \\
\hline NO (10) & $0.67 \pm 0 a$ & $0.53 \pm 0 c$ & $0.60 \mathrm{ab}$ & $0.55 \pm 0$ & $0.51 \pm 0$ & $0.53 b$ \\
\hline NO (20) & $0.66 \pm 0 a$ & $0.55 \pm 0 c$ & $0.60 \mathrm{ab}$ & $0.54 \pm 0$ & $0.52 \pm 0$ & $0.53 b$ \\
\hline Mean (ST) & $0.66 a$ & $0.54 b$ & & $0.55 a$ & $0.53 b$ & \\
\hline \multicolumn{7}{|c|}{$\mathrm{SSC} / \mathrm{TA}$} \\
\hline Control & $17.4 \pm 0.2$ & $23.4 \pm 0.2$ & 20.4 & $21.1 \pm 0.1$ & $20.7 \pm 0.3$ & 20.9 \\
\hline NO (5) & $19.1 \pm 0.3$ & $23.3 \pm 0.2$ & 21.2 & $20.3 \pm 0.1$ & $22.5 \pm 0.4$ & 21.4 \\
\hline NO (10) & $18.6 \pm 0.1$ & $24.2 \pm 0.2$ & 21.4 & $20.8 \pm 0.4$ & $23.7 \pm 0.2$ & 22.2 \\
\hline NO (20) & $19.1 \pm 0.1$ & $23.2 \pm 0.1$ & 21.2 & $20.6 \pm 0.4$ & $23.0 \pm 0.4$ & 21.8 \\
\hline Mean (ST) & $18.6 \mathrm{~b}$ & $23.5 a$ & & $20.7 b$ & $22.5 a$ & \\
\hline
\end{tabular}

Data represent means of 4 replicate samples of 80 units for Midknight Valencia and Lane Late. Mean separation for significant analysis of variance within the columns and rows was tested using Duncan's multiple range test at $(P<0.05)$. Mean followed by the same letter is not significantly different within the columns or rows. No letters on the means within a column show effects of treatments were not significant. Standard error (SE \pm ). Treatments (Tr), Storage temperature (ST). 
Table 5. Glucose, fructose, sucrose and total sugars in Midknight Valencia and Lane Late sweet orange fruit influenced by different concentrations of NO fumigation and two cold storage temperatures $\left(4\right.$ or $\left.7^{\circ} \mathrm{C}\right)$ for 90 days followed by 10 days of simulated shelf conditions $\left(21 \pm 1^{\circ} \mathrm{C}\right)$.

\begin{tabular}{|c|c|c|c|c|c|c|}
\hline \multicolumn{7}{|c|}{ Glucose $\left(\mathrm{g} \mathrm{L}^{-1}\right)$} \\
\hline & Midknight Valencia & Lane Late & & & & \\
\hline $\begin{array}{l}\text { Treatments } \\
\left(\mu \mathrm{L} \mathrm{L}^{-1}\right)\end{array}$ & $4{ }^{\circ} \mathrm{C}$ & $7^{\circ} \mathrm{C}$ & Mean (Tr) & $4{ }^{\circ} \mathrm{C}$ & $7^{\circ} \mathrm{C}$ & Mean $(\mathrm{Tr})$ \\
\hline Control & $14.8 \pm 0.1 \mathrm{~b}$ & $17.2 \pm 0.2 \mathrm{a}$ & $16.0 \mathrm{a}$ & $14.4 \pm 0.1$ & $14.7 \pm 0.2$ & 14.5 \\
\hline NO (5) & $12.2 \pm 0.2 c$ & $15.5 \pm 0.2 b$ & $13.9 b$ & $12.1 \pm 0.3$ & $15.3 \pm 0.4$ & 13.7 \\
\hline NO (10) & $12.2 \pm 0 c$ & $14.9 \pm 0 b$ & $13.5 b$ & $14.6 \pm 0.3$ & $16.0 \pm 0.1$ & 15.3 \\
\hline NO (20) & $14.1 \pm 0.4 b$ & $14.8 \pm 0.2 b$ & $14.5 b$ & $12.9 \pm 0.4$ & $15.7 \pm 0.3$ & 14.3 \\
\hline Mean (ST) & $13.3 \mathrm{~b}$ & $15.6 a$ & & $13.5 b$ & $15.4 a$ & \\
\hline \multicolumn{7}{|c|}{ Fructose $\left(\mathrm{g} \mathrm{L}^{-1}\right)$} \\
\hline Control & $23.4 \pm 0.3 b$ & $25.8 \pm 0.2 a$ & $24.6 a$ & $21.6 \pm 0.4$ & $22.7 \pm 0.3$ & 22.1 \\
\hline NO (5) & $21.1 \pm 0.1 \mathrm{~cd}$ & $23.6 \pm 0.3 b$ & $22.4 b c$ & $20.4 \pm 0.4$ & $23.1 \pm 0.6$ & 21.8 \\
\hline NO (10) & $20.8 \pm 0.1 d$ & $23.0 \pm 0 b$ & $21.9 c$ & $23.5 \pm 0.1$ & $23.5 \pm 0.3$ & 23.5 \\
\hline NO (20) & $23.6 \pm 0.3 b$ & $22.5 \pm 0.3 b c$ & $23.1 b$ & $23.4 \pm 0.4$ & $23.6 \pm 0.2$ & 23.5 \\
\hline Mean (ST) & $22.2 b$ & $23.7 a$ & & 22.2 & 23.2 & \\
\hline \multicolumn{7}{|c|}{ Sucrose $\left(\mathrm{g} \mathrm{L}^{-1}\right)$} \\
\hline Control & $57.5 \pm 0.4$ & $51.5 \pm 0.1$ & $54.5 a$ & $55.4 \pm 1.2$ & $50.4 \pm 0.9$ & 52.9 \\
\hline NO (5) & $51.7 \pm 0.4$ & $51.7 \pm 0.7$ & $51.7 b$ & $50.6 \pm 0.4$ & $51.6 \pm 1.3$ & 51.1 \\
\hline NO (10) & $52.7 \pm 0.4$ & $51.5 \pm 0.6$ & $52.7 a b$ & $53.6 \pm 0.4$ & $51.3 \pm 0.3$ & 52.5 \\
\hline NO (20) & $50.5 \pm 0.4$ & $49.8 \pm 0.1$ & $50.5 b$ & $54.4 \pm 0.7$ & $50.6 \pm 0.7$ & 52.5 \\
\hline Mean (ST) & $53.6 a$ & $51.1 \mathrm{~b}$ & & 53.5 & 51.0 & \\
\hline \multicolumn{7}{|c|}{ Total sugars $\left(\mathrm{g} \mathrm{L}^{-1}\right)$} \\
\hline Control & $95.7 \pm 0.2$ & $94.5 \pm 0.2$ & $95.1 a$ & $90.1 \pm 2.0$ & $87.8 \pm 1.4$ & 89.0 \\
\hline NO (5) & $84.9 \pm 0.3$ & $90.8 \pm 0.3$ & $87.9 \mathrm{~b}$ & $83.1 \pm 0.9$ & $84.7 \pm 0.4$ & 83.9 \\
\hline NO (10) & $87.0 \pm 0.4$ & $89.4 \pm 0.4$ & $88.2 b$ & $91.7 \pm 0.7$ & $90.8 \pm 0.1$ & 91.2 \\
\hline NO (20) & $89.0 \pm 1.0$ & $87.1 \pm 1.0$ & $88.0 \mathrm{~b}$ & $90.7 \pm 1.1$ & $89.9 \pm 1.1$ & 90.3 \\
\hline Mean (ST) & 89.1 & 90.4 & & 88.9 & 88.3 & \\
\hline
\end{tabular}

Dean followed by the same letter is not significantly different within the columns or rows. Standard error (SE \pm ). Treatments (Tr). Storage temperature (ST).

Table 6. Vitamin C and total antioxidants in Midknight Valencia and Lane Late sweet orange fruit influenced by different concentrations of NO fumigation and two cold storage temperatures $\left(4\right.$ or $\left.7^{\circ} \mathrm{C}\right)$ for 90 days followed by 10 days of simulated shelf conditions $\left(21 \pm 1^{\circ} \mathrm{C}\right)$.

\begin{tabular}{|c|c|c|c|c|c|c|}
\hline \multicolumn{7}{|c|}{ Vitamin $\mathrm{C}\left(\mathrm{mg} \mathrm{L}^{-1}\right)$} \\
\hline & Midknight Valencia & Lane & & & & \\
\hline $\begin{array}{l}\text { Treatments } \\
\left(\mathrm{NO} \mu \mathrm{L} \mathrm{L}^{-1}\right)\end{array}$ & $4^{\circ} \mathrm{C}$ & $7^{\circ} \mathrm{C}$ & $\begin{array}{l}\text { Mean } \\
(\mathrm{Tr})\end{array}$ & $4{ }^{\circ} \mathrm{C}$ & $7^{\circ} \mathrm{C}$ & $\begin{array}{l}\text { Mean } \\
(\mathrm{Tr})\end{array}$ \\
\hline Control & $379.2 \pm 4.6 a$ & $372.4 \pm 14.5 a b$ & $375.8 a$ & $317.4 \pm 2.7$ & $334.9 \pm 7.3$ & $326.1 \mathrm{a}$ \\
\hline NO (5) & $298.6 \pm 6.0 c$ & $416.1 \pm 1.9 a$ & $357.4 a$ & $290.2 \pm 5.4$ & $307.4 \pm 9.8$ & $298.8 b$ \\
\hline NO (10) & $217.7 \pm 8.7 d$ & $307.0 \pm 8.0 \mathrm{bc}$ & $262.4 b$ & $275.6 \pm 3.3$ & $277.6 \pm 1.0$ & $276.6 b$ \\
\hline NO (20) & $232.6 \pm 13.4 d$ & $354.0 \pm 8.4 a b c$ & $293.3 b$ & $284.7 \pm 6.6$ & $308.0 \pm 8.4$ & $296.4 b$ \\
\hline Mean (ST) & $282.0 \mathrm{~b}$ & $362.4 a$ & & 292.0 & 307.0 & \\
\hline \multicolumn{7}{|c|}{ Total Antioxidants $\left(\mu \mathrm{M}\right.$ Trolox $\left.\mathrm{L}^{-1}\right)$} \\
\hline Control & $333.5 \pm 8.0 c$ & $405.1 \pm 8.8 \mathrm{ab}$ & $369.3 b$ & $356.2 \pm 14.7$ & $356.4 \pm 9.2$ & 356.3 \\
\hline NO (5) & $447.0 \pm 4.1 a$ & $385.9 \pm 8.2 \mathrm{abc}$ & $416.5 a$ & $334.4 \pm 7.9$ & $343.5 \pm 8.5$ & 339.0 \\
\hline NO (10) & $334.1 \pm 11.1 \mathrm{c}$ & $365.1 \pm 11.0 b c$ & $349.6 b$ & $338.5 \pm 4.7$ & $327.3 \pm 4.2$ & 332.9 \\
\hline NO (20) & $390.8 \pm 9.3 a b c$ & $375.8 \pm 12.0 \mathrm{bc}$ & 383.3ab & $347.3 \pm 10.2$ & $329.6 \pm 8.8$ & 338.5 \\
\hline Mean (ST) & 376.3 & 383.0 & & 344.1 & 339.2 & \\
\hline
\end{tabular}

Mean followed by the same letter is not significantly different within the columns or rows. Standard error (SE \pm ). Treatments (Tr), Storage temperature (ST).

and Miller, 2004). Fumigation of the climacteric Chinese bayberry (Myrica rubra) fruit with NO gas in nitrogen for $2 \mathrm{~h}$ suppressed ethylene production, total phenolic and DPPH radical scavenging activity (Wu et al., 2012).

All NO fumigation treatments were able to reduce mean weight loss percentage only in Lane Late (Table 2), which may be ascribed to the genotypic differences between both cultivars. It may also be argued that reduction in water loss with NO fumigation seems to play some role in reducing $\mathrm{Cl}$. Previously, increased moisture loss was significantly correlated with an increased $\mathrm{Cl}$ in Lanes Late navel orange (Henroid et al., 2005). Furthermore, Ku et al. (2000) also reported that NO fumigated fruit, vegetables and flowers exhibited $20 \%$ reduced water loss due to reduced transpiration rate. All the NO fumigation treatments significantly reduced the TA (\%) in the juice of Midknight
Valencia and Lane Late. On the other hand, Singh et al. (2009) reported that NO treatments (10 or $20 \mu \mathrm{L} \mathrm{L}^{-1}$ ) increased TA (\%) in Japanese plums cV. Amber Jewel. In addition, NO fumigation treatments irrespective of the concentrations applied did not affect the level of glucose, fructose, sucrose and total sugars in Lane Late only (Table 5). Whilst, in Midknight Valencia, NO fumigation reduced the levels of individual and total sugars which suggest that NO fumigation affect sugar metabolism in the orange fruit in a genotype-dependent manner. Our findings are in line with Zaharah and Singh (2011) who reported that NO fumigation treatments did not influence the concentration of sucrose and glucose in the pulp of mango fruit as compared to nonfumigated fruit. 


\section{Materials and methods}

Two independent experiments were conducted using Midknight Valencia and Lane Late sweet orange cultivars to evaluate the effects of different concentrations of NO fumigation and cold storage temperature on $\mathrm{Cl}$ incidence and fruit quality.

\section{Fruit material}

Mature fruit of Midknight Valencia and Lane Late (Citrus sinensis (L.) Osbeck) were harvested from a commercial orchard Moora Citrus ( $30^{\circ} 35^{\prime} \mathrm{S} / 115^{\circ} 55^{\prime} \mathrm{E}$ ), Dandaragan, Western Australia during 2015. The trees of Midknight Valencia and Lane Late were nine and seven years old respectively. The Midknight Valencia and Lane Late both were on Carrizo citrange (Citrus sinensis (L.) Osbeck $x$ Poncirus trifoliata Raf.) rootstock. The planting space was 2.7 tree to tree and $7.5 \mathrm{~m}$ between rows and a north-south orientation was used in the experiments. The fruit were randomly harvested around the tree canopy. Fruit were transported directly in a closed container to the Horticulture Research Laboratory, Curtin University, Perth, WA, within four hours of harvest. All fruit were visually observed for diseases and blemishes.

Experiment 1: Effects of different concentrations of NO fumigation and cold storage temperature on $\mathrm{Cl}$ incidence in Lane Late during 2015.

The first experimental trial was conducted on Lane Late. Different concentrations of NO $\left(5,10\right.$ or $\left.20 \mu \mathrm{L} \mathrm{L}^{-1}\right)$ were used to fumigate the fruit in a sealed plastic container $(67 \mathrm{~L})$. NO was obtained from a cylinder containing $4810 \pm 100 \mu \mathrm{L} \mathrm{L}^{-1} \mathrm{NO}$ in a nitrogen gas (BOC Gases Ltd., Sydney, NSW, Australia) and injected into the container through an injection port on the container lid by using $(50 \mathrm{~mL})$ of the syringe. Fruit were kept in a NO atmosphere for 2 hours at ambient temperature $\left(21 \pm 1{ }^{\circ} \mathrm{C}\right)$. NO has been reported to be effectively stable at low concentrations and as a result, oxygen gas $\left(\mathrm{O}_{2}\right)$ in the container was not depleted and short treatment times required for the fruit to be treated in normal air (Soegiarto et al., 2003). Untreated fruit were placed in the plastic container for the same period of time without any treatment. The experimental designed was completely randomised with two factors including NO fumigation treatments and storage temperatures. All the treatments and control were replicated four times. Each replication included twenty fruit. Following the NO fumigation treatments, fruit were weighed before being stored at two cold storage temperatures of $4{ }^{\circ} \mathrm{C}$ and $7{ }^{\circ} \mathrm{C}$ for 90 days with (85-90 \%) relative humidity. $\mathrm{Cl}$ incidence (\%) was recorded following 90 days cold storage and 10 days simulated shelf conditions $\left(21 \pm 1^{\circ} \mathrm{C}\right)$ and fruit weight loss was recorded only at 90 days after cold storage. Additionally, various fruit quality variables such as fruit firmness, SSC (\%), TA (\%), SSC/TA, sugars, vitamin C and total antioxidants were also determined from the fruit stored at both $4{ }^{\circ} \mathrm{C}$ and $7{ }^{\circ} \mathrm{C}$ for 90 days and followed by 10 days in simulated shelf conditions $\left(21 \pm 1^{\circ} \mathrm{C}\right)$.
Experiment 2: Effects of different concentrations of NO fumigation and cold storage temperature on $\mathrm{Cl}$ incidence in Midknight Valencia during 2015.

In the same year, the first experiment was repeated keeping the same treatments of NO, storage temperatures, time period, and experimental design but using late maturing sweet orange Midknight Valencia. Twenty fruit were also included in each replication and replicated four times. In addition, all the parameters noted in experiment 1 were recorded for Midknight Valencia.

\section{Observations recorded}

The following variables were recorded during the course of experiments.

\section{Chilling Injury incidence (\%)}

Following 90 days cold storage and 10 days simulated shelf conditions $\left(21 \pm 1{ }^{\circ} \mathrm{C}\right)$, the symptoms of $\mathrm{Cl}$ on the surface of individual fruit in Midknight Valencia and Lane Late were recorded. In each replication, the fruit exhibiting symptoms of chilling injury (chill injured fruit) were counted from the total number of fruit. Using the following formula per cent chilling injury incidence was calculated.

Chilling injury incidence $(\%)=$ Number of chill injured fruit $\div$ Total number of fruit $x 100$.

\section{Determination of loss of fruit weight}

Initial fruit weight of Midknight Valencia and Lane Late fruit was recorded using a digital weigh balance at the commencement of cold storage. Following 90 days of cold storage, the final weight of the fruit was noted. The loss of fruit weight for 90 days cold storage was computed using the following formula and expressed as a per cent.

Weight loss $(\%)=\frac{(\text { Initial weight }- \text { Final weight }) \times 100}{\text { Initial weight }}$

Fruit firmness

A texture profile analyser (TPA Plus, AMETEK Lloyd Instruments Ltd, Fareham, UK) interfaced with Nexygen ${ }^{\circledR} 4.6$ software was used to estimate the fruit firmness in Midknight Valencia and Lane Late by following the methods earlier detailed by Hussain (2014). Fruit firmness was expressed as newtons $(\mathrm{N})$.

\section{SSC and TA}

The SSC in the fresh juice extracted from ten randomly selected fruit per replication in Midknight Valencia and Lane Late was assessed by utilising a digital refractometer (AtagoPalette PR 101, Atago CO. Ltd, Itabashi-Ku, and Tokyo, Japan) and expressed as a percentage, and the acidity percentage was determined by titrating the juice against $0.1 \mathrm{~N} \mathrm{NaOH}$ using 2-3 drops of phenolphthalein as an indicator to a pink colour end point. TA was expressed as per cent citric acid. 


\section{Determination of sugars}

The levels of individual sugars in the juice of Midknight Valencia and Lane Late were quantified using reverse-phase high-performance liquid chromatography system (RP-HPLC; Waters, Milford, MA, USA) equipped with refractive index detector. The detailed conditions of analysis have been reported earlier in detail by Hussain (2014) and Rehman et al. (2018). All the individual sugars were expressed as ( $\left.\mathrm{g} \mathrm{L}^{-1}\right)$ fresh juice.

\section{Determination of vitamin C and total antioxidants}

The level of vitamin $C$ and total antioxidants in the fresh juice of ten randomly selected fruit from each cultivar of Midknight Valencia and Lane Late were estimated by using a UV/VIS spectrometer (Jenway spectrophotometer Model 6405, Dunmow, Essex, UK) as per the previously reported method (Hussain, 2014; Brand-Williams et al., 1995 respectively). The concentration of vitamin $C$ in the juice of both cultivars was calculated by using the standard curve of L-ascorbic acid and expressed as ( $\left.\mathrm{mg} \mathrm{L}^{-1}\right)$ of fresh juice. On the other hand, the concentration of total antioxidants was calculated by using the standard curve of 6-hydroxy-2, 5, 7, 8-tetramethylchromane-2-carboxylic acid (Trolox) and expressed as a $\mu \mathrm{M}$ Trolox equivalent antioxidant activity (TEAC) $\left(\mathrm{L}^{-1}\right)$ fresh juice basis.

\section{Statistical analysis}

The experimental data were analysed by two-way analysis of variance (ANOVA) using GenStat 14th edition (release 14.1; Lawes Agricultural Trust, Rothamsted Experimental Station, Rothamsted, UK). Mean separations were tested by Duncan's multiple range test $(P<0.05)$.

\section{Conclusion}

All the NO fumigation treatments $\left(5,10\right.$ or $\left.20 \mu \mathrm{L} \mathrm{L} \mathrm{L}^{-1}\right)$ significantly reduced the $\mathrm{Cl}$ as compared to the control irrespective of storage temperature in Midknight Valencia and Lane Late, but NO $\left(10 \mu \mathrm{L} \mathrm{L}^{-1}\right)$ treatment was most effective in both cultivars. All the NO fumigation treatments reduced per cent weight loss in Lane Late only. NO fumigation treatments irrespective of the concentration applied reduced the concentrations of glucose, fructose, sucrose and total sugars in the juice of Midknight Valencia only.

\section{Acknowledgements}

Muneer Rehman gratefully acknowledges the Australian Centre for International Agricultural Research (ACIAR) for granting the John Allwright Fellowship all through his PhD. We are thankful to Mr Shane Kay, Moora Citrus for providing oranges required for this research and allowing us to access to the orchard. Ms Robyn $O^{\prime}$ Grady is gratefully acknowledged for proofreading the manuscript

\section{References}

Besson-Bard A, Pugin A, Wendehenne D (2008) New insights into nitric oxide signalling in plants. Annu Rev Plant Biol. 59: 21-39.

Brand-Williams W, Cuvelier ME, Berset CLWT (1995) Use of a free radical method to evaluate antioxidant activity. LWTFood Sci Technol. 28(1): 25-30.

Duan X, Su X, You Y, Qu H, Li Y, Jiang Y (2007) Effect of nitric oxide on pericarp browning of harvested longan fruit in relation to phenolic metabolism. Food Chem. 104(2): 571576.

Flores FB, Sánchez-Bel P, Valdenegro M, Romojaro F, Martínez-Madrid MC, Egea MI (2008) Effects of a pretreatment with nitric oxide on peach (Prunus persica L.) storage at room temperature. Eur Food Res Technol. 227(6): 1599.

Ghorbani B, Pakkish Z, Khezri M (2018) Nitric oxide increases antioxidant enzyme activity and reduces chilling injury in orange fruit during storage. N Z J Crop Hortic Sci. 46: 1-16.

Henriod RE, Gibberd MR, Treeby MT (2005) Storage temperature effects on moisture loss and the development of chilling injury in Lanes Late navel orange. Aust J Exp Agr. 45(4): 453-458.

Huque R, Wills RBH, Pristijono P, Golding JB (2013) Effect of nitric oxide (NO) and associated control treatments on the metabolism of fresh-cut apple slices in relation to the development of surface browning. Postharvest Biol Technol. 78: 16-23.

Hussain Z (2014) Role of polyamines and ethylene in creasing of sweet orange fruit. PhD Thesis, Department of Environment and Agriculture, Curtin University of Technology, Western Australia.

Kader AA (2002) Postharvest technology of horticultural crops (Vol. 3311). University of California Agriculture and Natural Resources.

Ku VV, Wills RB, Leshem YAY (2000) Use of nitric oxide to reduce postharvest water loss from horticultural produce. J Horti Sci Biotechnol. 75(3): 268-270.

Ladaniya MS (2010) Citrus Fruit: Biology, Technology and Evaluation. Academic Press (Elsevier), San Diego, CA.

Li XP, Wu B, Guo Q, Wang JD, Zhang P, Chen WX (2014) Effects of nitric oxide on postharvest quality and soluble sugar content in papaya fruit during ripening. J Food Process Pres. 38(1): 591-599.

Liu LQ, Yu DONG, Guan JF (2011) Effects of nitric oxide on the quality and pectin metabolism of 'Yali' pears during cold storage. ASC. 10(7):1125-1133.

Lyons JM (1973) Chilling injury in plants. Annu Rev Plant Physiol. 24(1): 445-466.

Manjunatha G, Lokesh V, Neelwarne B (2010) Nitric oxide in fruit ripening: trends and opportunities. Biotechnol Adv. 28(4): 489-499.

Millar AH, Day DA (1996) Nitric oxide inhibits the cytochrome oxidase but not the alternative oxidase of plant mitochondria. FEBS Lett. 398(2-3): 155-158.

Rehman M, Singh Z, Khurshid T (2018) Pre-harvest spray application of abscisic acid (S-ABA) regulates fruit colour development and quality in early maturing $M 7$ navel orange. Sci Horti. 229: 1-9. 
Reuther W (1989) The Citrus Industry: Crop protection, postharvest technology, and early history of citrus research in California (Vol. 3326). UCANR Publications.

Sala JM (1998) Involvement of oxidative stress in chilling injury in cold-stored mandarin fruits. Postharvest Biol Technol. 13(3): 255-261.

Sala JM, Sanchez-Ballesta MT, Alférez F, Mulas M, Zacarias L, Lafuente MT (2005) A comparative study of the postharvest performance of an ABA-deficient mutant of oranges: II. Antioxidant enzymatic system and phenylalanine ammonia-lyase in non-chilling and chilling peel disorders of citrus fruit. Postharvest Biol Technol. 37(3): 232-240.

Singh SP, Singh Z, Swinny EE (2009) Postharvest nitric oxide fumigation delays fruit ripening and alleviates chilling injury during cold storage of 'Japanese' plums (Prunus salicina Lindell). Postharvest Biol Technol. 53(3): 101-108.

Soegiarto L, Wills RBH, Seberry JA, Leshem YY (2003) Nitric oxide degradation in oxygen atmospheres and rate of uptake by horticultural produce. Postharvest Biol Technol. 28(2), 327-331.

Wang Y, Luo Z, Du R, Liu Y, Ying T, Mao L (2013) Effect of nitric oxide on antioxidative response and proline metabolism in banana during cold storage. J Agri Food Chem. 61(37): 8880-8887.

Watkins C, Miller WB (2004) A summary of physiological processes or disorders in fruits, vegetables and ornamental products those are delayed or decreased, increased, or unaffected by the application of 1methylcyclopropene (1-MCP). HortSci. 39(4), 816-816.

Wendehenne D, Pugin A, Klessig DF, Durner J (2001) Nitric oxide: Comparative synthesis and signalling in animal and plant cells. Trends Plant Sci. 6, 177-183.

Wills RBH, Ku VVV, Leshem YY (2000) Fumigation with nitric oxide to extend the postharvest life of strawberries. Postharvest Biol Technol. 18(1): 75-79.

Wink DA, Mitchell JB (1998) Chemical biology of nitric oxide: insights into regulatory, cytotoxic, and cytoprotective mechanisms of nitric oxide. Free Radic Biol Med. 25(4): 434-456.

Wu B, Guo Q, Li Q, Ha Y, Li X, Chen W (2014) Impact of postharvest nitric oxide treatment on antioxidant enzymes and related genes in banana fruit in response to chilling tolerance. Postharvest Biol Technol. 92: 157-163

Wu F, Yang H, Chang Y, Cheng J, Bai S, Yin J (2012) Effects of nitric oxide on reactive oxygen species and antioxidant capacity in 'Chinese' Bayberry during storage. Sci Horti. 135: 106-111.
Xie Z, Duan L, Tian X, Wang B, Eneji AE, Li Z (2008) Coronatine alleviates salinity stress in cotton by improving the antioxidative defence system and radical-scavenging activity. J Plant Physiol. 165(4): 375-384.

Xu MJ, Dong JF, Zhu MY (2005) Nitric oxide mediates the fungal elicitor-induced hypericin production of (Hypericum perforatum) cell suspension cultures through a jasmonicacid-dependent signal pathway. Plant Physiol. 139(2): 991998.

Xu M, Dong J, Zhang M, Xu X, Sun L (2012) Cold-induced endogenous nitric oxide generation plays a role in chilling tolerance of loquat fruit during postharvest storage. Postharvest Biol Technol. 65: 5-12.

Yang H, Wu F, Cheng J (2011) Reduced chilling injury in cucumber by nitric oxide and the antioxidant response. Food Chem. 127(3): 1237-1242.

Yin J, Bai S, Wu F, Lu G, Yang H (2012) Effect of nitric oxide on the activity of phenylalanine ammonia-lyase and antioxidative response in sweet potato root in relation to wound-healing. Postharvest Biol Technol. 74: 125-131.

Zaharah SS, Singh Z (2011) Postharvest nitric oxide fumigation alleviates chilling injury, delays fruit ripening and maintains quality in cold-stored 'Kensington' Pride mango. Postharvest Biol Technol. 60(3): 202-210.

Zhao R, Sheng J, Lv S, Zheng Y, Zhang J, Yu M, Shen L (2011) Nitric oxide participates in the regulation of LeCBF1 gene expression and improves cold tolerance in harvested tomato fruit. Postharvest Biol Technol. 62(2): 121-126.

Zhu LQ, Zhou J, Zhu SH (2010) Effect of a combination of nitric oxide treatment and intermittent warming on prevention of chilling injury of 'Feicheng' peach fruit during storage. Food Chem. 121(1): 165-170.

Zhu SH, Zhou J (2007) Effect of nitric oxide on ethylene production in strawberry fruit during storage. Food Chem. 100(4): 1517-1522.

Zhu S, Sun L, Zhou J (2009) Effects of nitric oxide fumigation on the phenolic metabolism of postharvest 'Chinese' winter jujube (Zizyphus jujuba Mill. cv. Dongzao) in relation to fruit quality. LWT-Food Sci Technol. 42(5): 1009-1014.

Zhu S, Sun L, Liu M, Zhou J (2008). Effect of nitric oxide on reactive oxygen species and antioxidant enzymes in kiwifruit during storage. J Sci Food Agri. 88(13): 2324-2331.

Zottini M, Formentin E, Scattolin M, Carimi F, Lo Schiavo F, Terzi M (2002) Nitric oxide affects plant mitochondrial functionality in vivo. FEBS Lett. 515(1-3): 75-78. 